\title{
Working
}

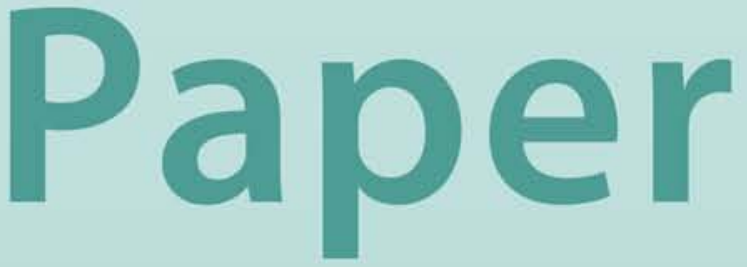




\section{A Simultaneous Equations Model for World Crude Oil and Natural Gas Markets}

Noureddine Krichene 


\title{
IMF Working Paper
}

\author{
African Department
}

\section{A Simultaneous Equations Model for World Crude Oil and Natural Gas Markets}

\author{
Prepared by Noureddine Krichene ${ }^{1}$ \\ Authorized for distribution by Reza Vaez-Zadeh
}

February 2005

\begin{abstract}
This Working Paper should not be reported as representing the views of the IMF. The views expressed in this Working Paper are those of the author(s) and do not necessarily represent those of the IMF or IMF policy. Working Papers describe research in progress by the author(s) and are published to elicit comments and to further debate.

A model for world crude oil and natural gas markets is estimated. It confirms low price and high income elasticities of demand for both crude oil and natural gas, which explains the market power of oil producers and price volatility following shocks. The paper establishes a relationship between oil prices, changes in the nominal effective exchange rate (NEER) of the U.S. dollar, and the U.S. interest rates, thereby identifying demand shocks arising from monetary policy. Both interest rates and the NEER are shown to influence crude prices inversely. The results imply that crude oil prices should be included in the policy rule equation of an inflation targeting model.
\end{abstract}

JEL Classification Numbers: C320, Q410

Keywords: Crude oil; Natural gas; Prices; Output; Demand; Supply; Elasticities; Interest rates; Nominal effective exchange rate; Impulse responses.

Author(s) E-Mail Address: nkrichene@imf.org

\footnotetext{
${ }^{1}$ The author gratefully acknowledges the help of Calvin A. McDonald, Hossein Samiei, Pierre van den Boogaerde, and Reza Vaez-Zadeh. Errors remain the author's responsibility.
} 


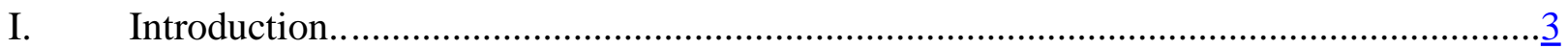

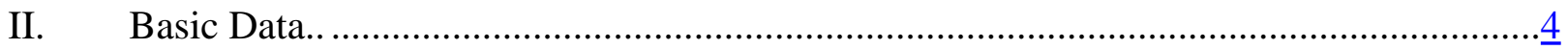

III. A Simultaneous Equations Model for Demand and Supply: Specification and Identification

IV. Estimation of the SEM for Crude Oil and Natural Gas. ................................................. 8

A. Short-Run Demand and Supply Elasticities..............................................................

B. Long-Run Demand and Supply Elasticities. ..............................................................11

C. Comparison with Findings in Other Studies and Implications for Market Equilibrium........................................................................................14

V. Relation Between Oil Prices, Interest Rates, and the U.S. Dollar NEER..........................16

VI. Extension and Solution of the SEM....................................................................19

A. Role of the NEER in the Crude Oil and Natural Gas Markets. ................................19

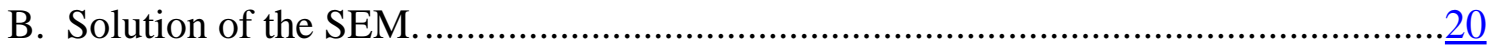

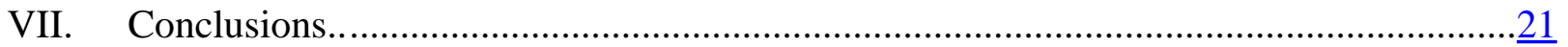

Appendix. Data Sources......................................................................................................

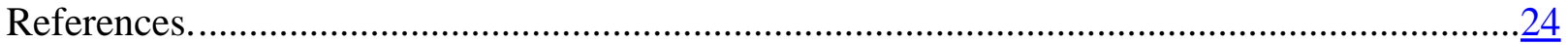

Tables

1. World Crude Oil and Natural Gas: Short-Run Demand and Supply Elasticities.............................................................................................. $\frac{9}{2}$

2. World Crude Oil and Natural Gas: Long-Run Elasticities. ............................................12

3. Estimates of Demand Elasticities from Other Energy Studies. .......................................15

4. Cointegrating Relations Between Crude Price, the NEER, and Interest Rates. ................18

5. World Crude Oil and Natural Gas: The SEM Extended to Include the NEER. ……….....20

Figures

1. World Crude Oil and Natural Gas: Output and Prices, 1918-2004................................... $\frac{5}{1}$

2. U.S. Interest Rates, U.S. Dollar NEER, and Crude Oil Price, 1970-2004.......................17

3. Impulse Responses from VAR for Crude Price, NEER, and Interest Rates.....................18

4. Actual and Fitted Values and Residuals of the SEM......................................................... 


\section{INTRODUCTION}

Crude oil and natural gas markets have been subject to shocks and consequently have been highly volatile. Demand and supply shocks cause large movements in oil and natural gas prices, which are followed by a dynamic response in both energy demand and supply and in the energy exploration and development activities. Modeling crude oil and natural gas markets is of paramount importance, not only because of the influence of energy on macroeconomic activity but also because of the role of energy in the investment plans of households and firms. Energy cost and efficiency have become a prime concern in these plans.

This paper presents a simultaneous equations model (SEM) of the world crude oil and natural gas markets. Estimation shows that price elasticities are low, whereas income elasticities are always significant and high. The elasticity estimates of the SEM are compared with some estimates of energy demand elasticities from the literature and firmly corroborate the hypothesis of extreme inelasticity of demand and supply to price changes. The implications of low price elasticities is that a small excess demand or supply may require large movements in prices to clear markets for crude oil and natural gas. Noting the importance of monetary policy in influencing aggregate demand and exchange rates, the paper attempts to establish a relation between oil prices, the U.S. dollar movements, as measured by changes in the nominal effective exchange rate (NEER), and the U.S. interest rates, and to identify, consequently, demand shocks arising from monetary policy. Both interest rates and NEER are shown to influence inversely crude prices; rising interest rates and an appreciating NEER tend to depress crude prices, whereas declining interest rates and a depreciating NEER have the opposite effect. As an implication of vulnerability to monetary shocks, coordination of monetary policy should explicitly include crude price volatility in the inflation target.

The paper is organized as follows. Section II describes the basic data for crude oil and natural gas output and prices over 1918-2004, thereby covering the periods before and after the oil shock that occurred in 1973. Section III presents a SEM that describes world demand and supply functions for crude oil and natural gas. Section IV estimates the SEM over 19182004, as well as the subperiods 1918-73 and 1974-2004, to account for structural changes that might have occurred. The choice of the subperiods was dictated by the stability of the world economy in 1950-73, the oil shocks, and the ensuing price volatility after 1973.

Section V discusses the relation between the crude price, the NEER, and interest rates using monthly, quarterly, and annual data for 1974-2004. Section VI extends the SEM by including the NEER as an additional exogenous variable and shows that the NEER has a significant impact on market equilibrium. The solution of the SEM is described in this section and is shown to track closely the actual data. Section VII concludes. 


\section{BASIC DATA}

In 2004, the production of crude oil stood at 84 million barrels a day (mbd) (Figure 1), increasing at an average rate of 1.3 percent per year during 1974-2004, compared with an average growth rate of 7.2 percent per year during 1918-73. OPEC's output stood at an alltime peak of $34 \mathrm{mbd}$ in 2004 and above the peak of $31 \mathrm{mbd}$ reached in 1973. Non-OPEC production stood at $50 \mathrm{mbd}$ in 2004, increasing steadily at 2.2 percent a year during 1974-2004, compared with 5.8 percent during 1918-73.

The sharp deceleration in world crude growth in the aftermath of the first oil shock may be seen as a long-term response of demand to dramatic jumps in oil prices. In addition to these jumps, many importing countries have introduced high taxes, with rates ranging between 200 percent and 400 percent of the import price of petroleum products, with a view to curbing petroleum demand and appropriating part of the producer's surplus. The demand response to high prices of petroleum products was in the form of inter-energy substitution and increasing efficiency in energy use. ${ }^{2}$

Natural gas production stood at 2,719 billion cubic meters a year (bcm/y) in 2004, compared with 1,233 bcm/y in 1973; it displayed the same growth pattern as oil output. However, it increased faster than oil production during both 1918-73 and 1974-2004, averaging 7.3 percent and 2.6 percent per year, respectively. The sharp deceleration in the growth of natural gas in the second subperiod may be seen as a demand adjustment to jumps in energy prices. Because a large part of natural gas is an associated gas, a deceleration in crude output would entail a similar deceleration in natural gas. Nonetheless, because natural gas growth was higher than that of crude oil during 1974-2004, there might have been a substitution of natural gas for liquid fuels.

The behavior of crude oil prices, ${ }^{3}$ both nominal and real, can be viewed over two distinct subperiods: 1918-73 and 1974-2004. In the initial period, prices exhibited a remarkable longterm stability, implying that demand and supply of crude oil were moving in harmony, as markets cleared without sizable excess demand or supply that could have entailed jumps in prices. In addition, the faster pace in natural gas supply kept the emergence of excess demand for crude oil in check.

\footnotetext{
${ }^{2}$ In OECD countries the demand for oil products is essentially accounted for by the transportation sector in 2004; the rest of the sectors relies on other forms of energy. The same phenomenon is taking place in developing countries.

${ }^{3}$ Nominal prices are measured in U.S. dollars per barrel. Real prices are measured in constant 1950 prices; the deflator is the consumer price index for the seven industrial countries.
} 
Figure 1. World Crude Oil and Natural Gas: Output and Prices, 1918-2004
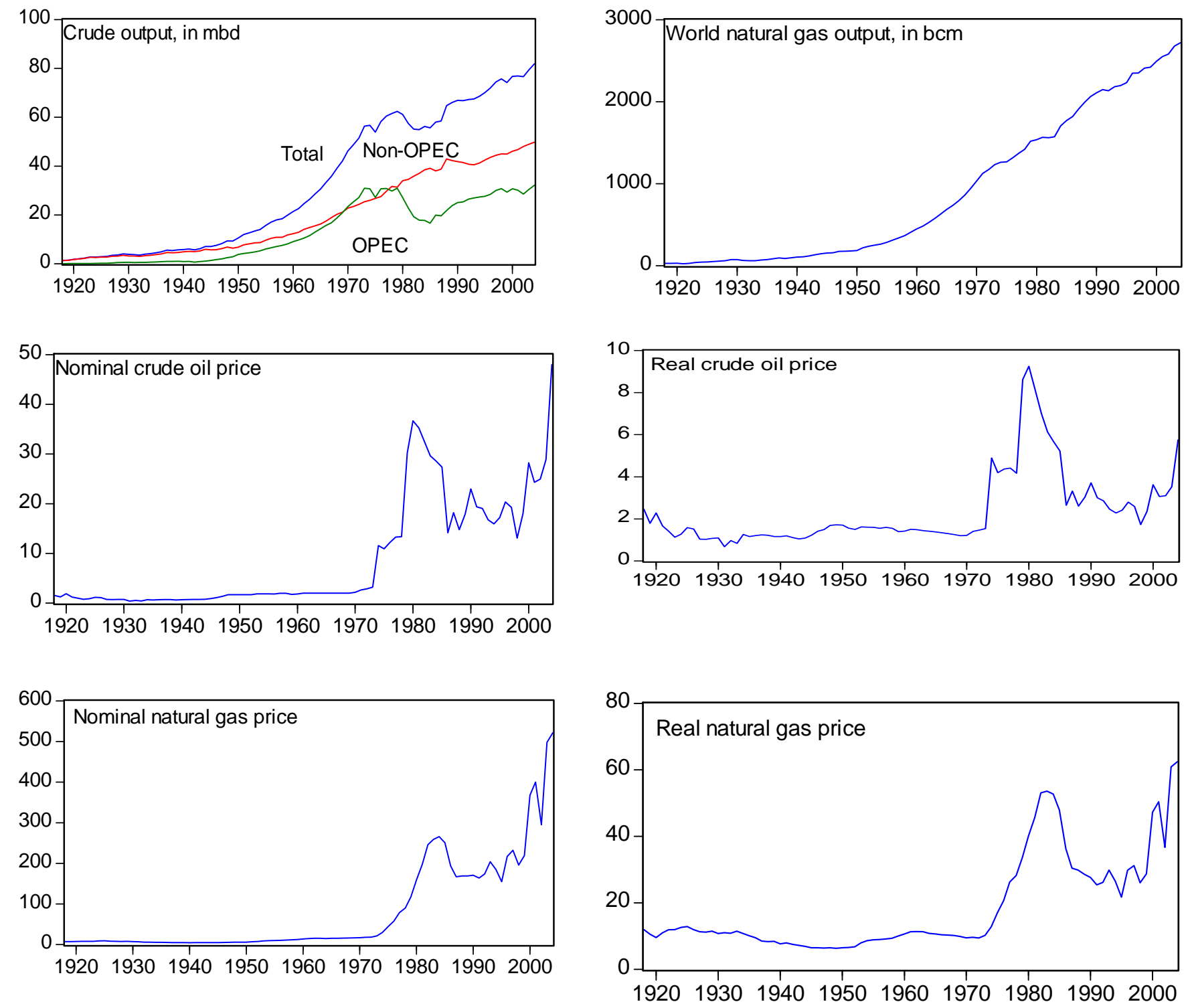

Source: See the Appendix for data sources. Crude oil output in million barrels/day, and natural gas output in billion cubic meters/year. Oil prices in US\$/barrel, and natural gas prices in US cents/1,000 cubic feet. Real prices are in 1950 prices.

The second period, 1974-2004, witnessed a series of oil price shocks and large fluctuations in crude prices. Nominal price rose to $\$ 36.7 / \mathrm{bl}$ in 1981 and even exceeded \$55/bl in 2004 . Nominal prices also fell drastically to $\$ 9-\$ 10 /$ bl in 1986 and 1999. A major turning point occurred in 1982 with the beginning of a persistent downturn in both nominal and real crude oil prices, reflecting the impact of the cumulative adjustment in demand. In fact, demandreducing policies, in the form of extremely high energy taxes and energy substitution, together with an increased supply outside of OPEC, have tended to depress real oil prices during 1986-1999. In 2000-2004, with the recovery of the Asian economies, extremely low interest rates worldwide stimulating aggregate demand as well as world oil demand, and the weakening of the dollar, a demand shock confronted with short-term fixed supply capacity 
has driven oil prices sharply upward. The supply response was very limited, with output increasing by only 2 percent a year during 2000-2004.

Natural gas prices ${ }^{4}$ increased rapidly in $1974-2004$ at 13.3 percent a year to an all-time peak of 521 cents/tcf in 2004. Real prices rose at 8.1 percent a year during 1974-2004 compared with a small decline at 0.3 percent a year during 1918-73. The relative price of natural gas in relation to crude oil has continuously appreciated, at 2 percent in 1918-73 and 6.1 percent in 1974-2004, indicating higher substitution of natural gas for liquid fuels.

\section{A Simultaneous Equations Model (SEM) FOR DEMAND AND SUPPLY: SPECIFICATION AND IDENTIFICATION}

A simultaneous demand and supply model for world crude oil and natural gas markets is specified. The hypothesis of rational expectations is adopted, given the role of market information in determining the supply behavior (Muth, 1961).

Crude oil demand: $y_{1}+\delta_{12} y_{2}+\gamma_{11} z_{1}+\gamma_{14} z_{4}=u_{1}$

Crude oil supply: $y_{1}+\delta_{22} y_{2}^{e}+\delta_{23} y_{3}+\gamma_{22} z_{2}+\gamma_{24} z_{4}=u_{2}$

Natural gas demand: $y_{3}+\delta_{34} y_{4}+\gamma_{31} z_{1}+\gamma_{34} z_{4}=u_{3}$

Natural gas supply: $\delta_{41} y_{1}+y_{3}+\delta_{44} y_{4}^{e}+\gamma_{43} z_{3}+\gamma_{44} z_{4}=u_{4}$,

where the definitions below apply; output, prices, and real GDP are in logarithm form:

$y_{1}=$ crude oil output, in millions of barrels per day;

$y_{2}=$ crude oil nominal price, in U.S. dollars per barrel;

$y_{2}^{e}=$ expected nominal price for crude oil, in U.S. dollars per barrel;

$y_{3}=$ natural gas output, in billions of cubic meters per year;

$y_{4}=$ natural gas nominal price, in U.S. cents per cubic feet;

\footnotetext{
${ }^{4}$ Natural gas prices are measured in U.S. cents per thousand cubic feet (tcf) at U.S. wellheads. Real prices are measured in constant 1950 prices, using the consumer price index of the seven industrial countries. Natural gas is not as tradable as crude oil. Although natural gas and liquefied natural gas are being exported, large quantities of natural gas can often be marketed only domestically. Domestic use of natural gas, through substitution, increases oil exports or reduces oil imports and thus affects trade flows of oil products.
} 
$y_{4}^{e}=$ expected real price for natural gas, in U.S. cents per cubic feet;

$\mathrm{z}_{1}=$ real GDP index for the seven industrial countries;

$\mathrm{z}_{2}=$ dummy variable for large swings in oil prices;

$\mathrm{z}_{3}=$ dummy variable for large swings in natural gas prices; and

$\mathrm{z}_{4}=\mathrm{a}$ constant term.

Each residual $u_{1}, u_{2}, u_{3}$, and $u_{4}$ is assumed to be serially uncorrelated, independently and identically distributed with a mean of zero and standard error $\sigma_{i}, i=1,2,3,4$, and uncorrelated with the predetermined and exogenous variables. It may be further assumed that demand and supply disturbances are uncorrelated, implying $E\left(u_{1} u_{2}\right)=0, E\left(u_{3} u_{4}\right)=0$, $E\left(u_{1} u_{3}\right)=0$, and $E\left(u_{2} u_{3}\right)=0$. The expected variables $y_{2}^{e}$ and $y_{4}^{e}$ are predetermined, and rationally formed: $y_{2}^{e}=E_{t-1}\left(y_{2} \mid I_{t-1}\right)$ and $y_{4}^{e}=E_{t-1}\left(y_{4} \mid I_{t-1}\right) ; I_{t-1}$ is the information set in period $t-1$ on which expectations $E_{t-1}\left(y_{i} \mid I_{t-1}\right)$ were based. Demand for crude oil is a function of its price and an indicator for world economic activity, which here is approximated by the real GDP of the seven industrial countries. The supply of crude oil is a function of its expected price at time $t-1$, the output of natural gas, ${ }^{5}$ and a dummy variable for shocks to oil prices. The demand for natural gas is a function of its price and real GDP. The supply of natural gas is a function of its expected price at time $t-1$, the output of crude oil, and a dummy variable for shocks to the natural gas price. Following McCallum (1976), the actual and expected prices are expressed as: $y_{2}=y_{2}^{e}+\eta_{2}$ and $y_{4}=y_{4}^{e}+\eta_{4}$, both $\eta_{2}$ and $\eta_{4}$ are forecast errors that are uncorrelated with $I_{t-1}$. In addition, the covariance restrictions will allow the use of the estimated residuals from equations (1) and (3), $\hat{u}_{1}$ and $\hat{u}_{3}$, as explanatory variables in equations (2) and (4), respectively (Hausman, Newey, and Taylor, 1987). Rearranging equations (2) and (4) by substituting for $y_{2}^{e}$ and $y_{4}^{e}$ and including $\hat{u}_{1}$ and $\hat{u}_{3}$, the model becomes:

$$
\begin{aligned}
& y_{1}+\delta_{12} y_{2}+\gamma_{11} z_{1}+\gamma_{14} z_{4}=u_{1} \\
& y_{1}+\delta_{22} y_{2}+\delta_{23} y_{3}+\gamma_{22} z_{2}+\gamma_{24} z_{4}+\delta_{u_{1}} \hat{u}_{1}=u_{2}+\delta_{22} \eta_{2} \\
& y_{3}+\delta_{34} y_{4}+\gamma_{31} z_{1}+\gamma_{34} z_{4}=u_{3}
\end{aligned}
$$

\footnotetext{
${ }^{5}$ Besides helping identification, the inclusion of natural gas output in the supply function for crude can be justified on the grounds that the two products are interdependent at the level of exploration, development, and production activities. The correlation coefficient between crude oil and natural gas production over 1918-2004 was 0.996 .
} 
$\delta_{41} y_{1}+y_{3}+\delta_{44} y_{4}+\gamma_{43} z_{3}+\gamma_{44} z_{4}+\delta_{u_{3}} \hat{u}_{3}=u_{4}+\delta_{44} \eta_{4}$

The model is identified: no one equation can be obtained as a linear combination of two or more equations. ${ }^{6}$ Given the dynamics of adjustment in demand and supply, lagged variables have to be introduced. Tests on the length of the lag seem to indicate that the optimal lag would be three or four periods. The model is estimated by a two-stage least-squares method to obtain short-run estimates. To strengthen confidence in these estimates, the model is reestimated in an error correction model (ECM). ${ }^{7}$ Long-run elasticities are estimated with the help of the ECM and with cointegration analysis; these two methods are appropriate for finding long-run relations in each identified equation of the model.

\section{ESTIMATION OF THE SEM FOR CRUDE OIL AND NATURAL GAS}

\section{A. Short-Run Demand and Supply Elasticities}

The demand for crude oil has a low short-run price elasticity: -0.05 in 1918-2004, -0.05 in 1918-73, and -0.003 in 1974-2004 (Table 1). These results show clearly that (i) crude oil demand is highly price-inelastic in the short run, as energy consumption is essentially determined by fixed capital; ${ }^{8}$ (ii) large price changes in 1974-2004 were not able to have a short-run effect on demand; and (iii) despite a long period, the short-run nature of this parameter has not significantly changed. The demand for crude oil turns out to be responsive to economic activity in the short run; the income elasticity was 0.54 (significant) in 1918-2004. Clearly, the demand for crude oil has become more sensitive to economic activity in the short run, as implied by the income elasticity, which rose from 0.43 (significant) in 1918-73 to 1.49 (significant) in 1974-2004. The extreme price inelasticity explains the large changes in prices due to a supply or demand shock. The price inelasticity explains also the importance of taxation in oil-importing countries to curb demand and reduce crude oil prices. ${ }^{9}$ An income elasticity averaging 0.54 during $1918-73$ explains the

${ }^{6}$ In addition, the order condition for identification of an equation within a system requires the number of excluded predetermined variables to be equal to or higher than the number of included endogenous variables minus one; or, equivalently, the number of exclusions has to be higher than or equal to the number of endogenous variables minus one. Because the number of endogenous variables is four, and the number of instrumental variables is six, the order condition is satisfied in each equation of the model.

${ }^{7}$ Consider the lag model: $y_{t}=\delta_{0}+\delta_{1} y_{t-1}+\gamma_{0} z_{t}+\gamma_{1} z_{t-1}+\varepsilon_{t}$; in an error correction form, it becomes $\Delta \mathrm{y}_{\mathrm{t}}=\delta_{0}+\gamma_{0} \Delta \mathrm{z}_{t}+\left(\delta_{1}-1\right) y_{t-1}+\left(\gamma_{0}+\gamma_{1}\right) z_{t-1}+\varepsilon_{t}$, or $\Delta \mathrm{y}_{\mathrm{t}}=\delta_{0}+\gamma_{0} \Delta z_{t}+\left(\delta_{1}-1\right)\left(y_{t-1}+\frac{\left(\gamma_{0}+\gamma_{1}\right)}{\left(\delta_{1}-1\right)} z_{t-1}\right)+\varepsilon_{t}$. The term $\left(y_{t-1}+\frac{\left(\gamma_{0}+\gamma_{1}\right)}{\left(\delta_{1}-1\right)} z_{t-1}\right)=0$

represents the long-run relation.

${ }^{8}$ Excess supplies of crude oil will add temporarily to inventories, and excess demand is met from inventories.

${ }^{9}$ Inelastic demand may require high tax rates to influence the quantities demanded. 
lack of pressure on prices, particularly during 1950-1973, which was a period of steady and fast world economic growth. The high-income elasticity in 1974-2004 explains in part the volatility of oil prices that follows a slowdown or an expansion of world growth.

Table 1. World Crude Oil and Natural Gas: Short-Run Demand and Supply Elasticities 1/

\begin{tabular}{|c|c|c|c|c|}
\hline & & Period 1918-2004 & Period 1918-73 & Period 1974-2004 \\
\hline \multicolumn{5}{|c|}{ A. Short-run elasticities (two-stage least squares) } \\
\hline \multicolumn{5}{|l|}{ Crude oil demand } \\
\hline Price elasticity & $\delta_{12}$ & $-0.05(-2.18)$ & $-0.05(-0.94)$ & $-0.003(-0.13)$ \\
\hline Income elasticity & $\gamma_{11}$ & $0.54(5.03)$ & $0.43(3.43)$ & 1.49 ( 3.23$)$ \\
\hline \multicolumn{5}{|l|}{ Crude oil supply } \\
\hline Price elasticity & $\delta_{22}$ & $-0.04(-1.97)$ & $-0.01(-0.33)$ & $-0.05(-2.11)$ \\
\hline Gas output elasticity & $\delta_{23}$ & $0.38(4.15)$ & $0.42(4.24)$ & $1.04(3.58)$ \\
\hline \multicolumn{5}{|l|}{ Natural gas demand } \\
\hline Price elasticity & $\delta_{34}$ & $-0.01(-0.21)$ & $-0.17(-0.78)$ & $-0.01(-0.38)$ \\
\hline Income elasticity & $\gamma_{31}$ & $0.77(7.06)$ & $0.70(4.63)$ & $0.80(2.94)$ \\
\hline \multicolumn{5}{|l|}{ Natural gas supply } \\
\hline Price elasticity & $\delta_{44}$ & $0.09(0.82)$ & $-0.32(-1.15)$ & $0.05(1.49)$ \\
\hline Oil output elasticity & $\delta_{41}$ & $0.88(3.73)$ & $1.04(3.60)$ & $0.35(3.24)$ \\
\hline \multicolumn{5}{|c|}{ B. Short-run elasticities in an error correction model } \\
\hline \multicolumn{5}{|l|}{ Crude oil demand } \\
\hline Price elasticity & $\delta_{12}$ & $-0.02(-0.78)$ & $0.04(1.03)$ & $-0.01(-0.64)$ \\
\hline Income elasticity & $\gamma_{11}$ & $0.36(3.60)$ & $0.30(2.92)$ & $1.41(4.30)$ \\
\hline \multicolumn{5}{|l|}{ Crude oil supply } \\
\hline Price elasticity & $\delta_{22}$ & $-0.02(-1.13)$ & $-0.01(-0.32)$ & $-0.03(-1.31)$ \\
\hline Gas output elasticity & $\delta_{23}$ & $0.41(4.52)$ & $0.46(4.74)$ & $0.84(3.03)$ \\
\hline \multicolumn{5}{|l|}{ Natural gas demand } \\
\hline Price elasticity & $\delta_{34}$ & $0.006(0.17)$ & $0.0004(0.003)$ & $0.008(0.46)$ \\
\hline Income elasticity & $\gamma_{31}$ & $0.73(7.96)$ & $0.74(6.48)$ & $0.85(3.83)$ \\
\hline \multicolumn{5}{|l|}{ Natural gas supply } \\
\hline Price elasticity & $\delta_{44}$ & $-0.03(-0.63)$ & $-0.05(-0.34)$ & $0.01(0.77)$ \\
\hline Oil output elasticity & $\delta_{41}$ & $0.53(4.95)$ & $0.62(4.00)$ & $0.33(3.04)$ \\
\hline
\end{tabular}

$1 / t$-ratio in parenthesis. 
The supply of crude oil has low short-run price elasticity: -0.04 in 1918-2004, -0.01 in 191873, and -0.05 in 1973-2004. Despite a long period, this parameter was stable. In the short run, supply is determined by existing capacity and cannot be expanded beyond this capacity. Supply is also determined by existing sales contracts and, after 1973, by OPEC's quotas. In addition, short-run price inelasticity is consistent with the rational expectations hypothesis and is characteristic of many industries, to the extent that producers may avoid short-term adjustment to price changes until the trend in prices becomes persistent owing to the labor and capital costs of the adjustment. Moreover, the negative sign of the supply price elasticity may derive from the short-run price inelasticity of the demand function. Recognizing the inelastic nature of short-run demand, producers may deliberately refrain from increasing output at the time of a price rise in order to preserve the gains in prices; conversely, producers may accept temporary discounts at a time of slack demand. There is also a lag-andlead aspect in supply: that is, a deliberate reduction in output could precede a price increase. Another explanation could be that the oil industry is operating on a short-term, downward supply curve, benefiting from economies of scale. Natural gas output had a significant effect on the supply of crude oil, with short-run elasticity estimated at 0.38 (1918-2004), 0.42 (1918-73), and 1.04 (1974-2004). The significant rise in natural gas elasticity during 1974-2004 shows strong correlation in the movements of crude oil and natural gas supply during this period. After 1973, oil price shocks seem to affect simultaneously and with the same intensity crude oil and natural gas production.

The demand for natural gas was similar to that for crude oil, with low and nonsignificant short-run price elasticity: -0.01 in $1918-2004,-0.17$ in $1918-73$, and -0.01 in 1974-2004. Determined by fixed capital, natural gas demand was, therefore, highly price inelastic in the short run. Real GDP was a main driving variable, with significant short-run income elasticities: 0.77 in 1918-2004, 0.70 in 1918-73, and 0.80 in 1974-2004. The rise in real GDP elasticity in 1974-2004 suggests that a structural change increased the importance of natural gas in economic activity. The lower-than-unity income elasticity would explain the lack of demand pressure on natural gas prices in 1918-2004. The natural gas supply function was quite similar to that of the crude oil. Short-run supply price elasticities were low and nonsignificant: 0.09 (1918-2004), -0.32 (1918-73), and 0.05 (1974-2004). These results establish that (i) the short-run price effect was small; namely, natural gas supply was determined by existing production capacity; and (ii) natural gas supply did not react immediately to changes in prices. The small value of the short-run price elasticity in 19742004 may indicate a likely emergence of a producers' power. It may also stem from the nature of the demand curve: knowing the inelasticity of demand, producers may deliberately restrain output in order to preserve surges in prices. It may be indicative also of a short-run downward supply curve arising from economies of scale in the industry. The crude oil output had a significant effect on the supply of natural gas. The short-run output elasticity was 0.88 in 1918-2004, 1.04 in 1918-73, and 0.35 in 1974-2004, implying interdependence in oil and natural gas production. An expansion in crude supply would likely be accompanied by a significant, although less than proportional, expansion in the supply of natural gas.

The reestimation of the model in the error correction form provides elasticities similar to those discussed above and, therefore, strengthens confidence in the estimates in level. The demand for crude oil continues to have low short-run price elasticities. The income elasticity 
is high, with a noticeable increase in 1974-2004. The supply of crude oil has a low short-run price elasticity. The natural gas output elasticity increased to 0.84 in 1974-2004 from 0.46 in 1918-73, demonstrating a stronger relation between crude oil and natural gas. The natural gas demand function in the ECM had short-run price elasticities that were low and insignificant. Income elasticities remained significant: 0.73 in 1918-2004, 0.74 in 1918-73, and 0.85 in 1974-2004. There was obviously an increase in the natural gas intensity in 1974-2004; however, the elasticity remained lower than unity. Therefore, changes in economic activity were exerting moderate pressure on the demand for natural gas. The supply function for natural gas in the ECM had no significant short-run price elasticity. The role of prices in influencing short-run supply remained weak. The negative price elasticity of supply in 19182004 seems to be related to the nature of demand, since producers could either set high prices and thereby prompt a decline in quantities demanded, or set quantities in such a way as to preserve price increases. In addition to prices, the supply of natural gas was significantly influenced by crude oil output; the elasticities were 0.53 in 1918-2004, 0.62 in 1918-73, and 0.33 in 1974-2004, implying strong interdependence between crude oil and natural gas production.

\section{B. Long-Run Demand and Supply Elasticities}

The estimation of long-run elasticities helps to determine the long-run equilibrium that will prevail in the crude oil and natural gas markets and the magnitude of adjustment in demand and supply. Higher elasticities would imply a smaller impact of oil shocks on oil prices and economic activity in the long run. Long-run elasticities were estimated using both the ECM and cointegration methods (Table 2). The existence of an integrating vector representing a long-run demand function for crude oil could not be rejected. The long-run price elasticity was significant: -0.27 in 1918-2004, -0.32 in 1918-73, and -0.26 in 1974-2004. Both the ECM and the cointegration methods show a significant drop in the demand elasticities in 1974-2004. The change in the magnitude of the elasticities was indicative of a major structural change in the market for crude oil. The big jumps in prices compressed long-run demand to a level that was highly inelastic to price changes, thereby creating a kink in the long-run demand curve. After the price shock in 1973, there was considerable energy saving and many forms of substitution to petroleum products. Moreover, high taxation in oilimporting countries helped to reduce demand to levels that were minimal for preserving growth, enhancing thus energy efficiency; ${ }^{10}$ it also helped to insulate domestic prices

${ }^{10}$ A model of the form: $z_{1}=A e^{\lambda t} y_{1}^{\alpha} y_{3}^{\beta}$, where $z_{1}$ is real GDP, and $y_{1}$ and $y_{3}$ are respectively crude and natural gas output, shows a substantial gain in efficiency, with $\hat{A}=0.38$ in 19181973, $\hat{A}=0.93$ in $1974-2004, \hat{\lambda}=0.1 \%$ in $1918-73$, and $\hat{\lambda}=0.9 \%$ in $1974-2004$. 
Table 2: World Crude Oil and Natural Gas: Long-Run Elasticities 1/

\begin{tabular}{|c|c|c|c|}
\hline & Period 1918-2004 & Period 1918-73 & Period 1974-2004 \\
\hline \multicolumn{4}{|c|}{ 1. Vector error correction method } \\
\hline \multicolumn{4}{|l|}{ Crude oil demand } \\
\hline Price elasticity & $-1.59(-4.02)$ & $-2.73(-3.52)$ & $-0.12(-1.86)$ \\
\hline Income elasticity & $3.48(5.60)$ & $3.43(5.46)$ & $0.62(7.47)$ \\
\hline \multicolumn{4}{|l|}{ Crude oil supply } \\
\hline Price elasticity & $0.16(2.46)$ & $0.44(3.50)$ & $0.23(3.96)$ \\
\hline Natural gas elasticity & $0.75(13.21)$ & $0.72(13.27)$ & $0.24(2.67)$ \\
\hline \multicolumn{4}{|l|}{ Natural gas demand } \\
\hline Price elasticity & $-0.45(-4.742)$ & $-2.79(-3.50)$ & $-0.06(-1.67)$ \\
\hline Income elasticity & $2.35(14.49)$ & 4.37 (6.69) & $0.96(9.66)$ \\
\hline \multicolumn{4}{|l|}{ Natural gas supply } \\
\hline Price elasticity & $0.16(5.51)$ & $0.16(1.42)$ & $0.21(6.51)$ \\
\hline Crude oil elasticity & $1.00(30.63)$ & $0.98(18.31)$ & $0.72(4.46)$ \\
\hline \multicolumn{4}{|c|}{ 2. Cointegration method } \\
\hline \multicolumn{4}{|l|}{ Crude oil demand } \\
\hline Price elasticity & $-0.27(-1.89)$ & $-0.32(-4.99)$ & $-0.26(-3.09)$ \\
\hline Income elasticity & $1.53(6.74)$ & $1.93(21.44)$ & $0.80(5.65)$ \\
\hline \multicolumn{4}{|l|}{ Crude oil supply } \\
\hline Price elasticity & $0.12(2.39)$ & $0.46(46.0)$ & $0.25(3.79)$ \\
\hline Natural gas elasticity & $0.78(16.98)$ & $0.73(16.59)$ & $0.45(18.0)$ \\
\hline \multicolumn{4}{|l|}{ Natural gas demand } \\
\hline Price elasticity & $-0.48(-2.40)$ & $-0.37(-2.00)$ & $-0.01(-1.11)$ \\
\hline Income elasticity & $1.78(5.17)$ & $2.35(16.71)$ & $0.88(23.73)$ \\
\hline \multicolumn{4}{|l|}{ Natural gas Supply } \\
\hline Price elasticity & $0.34(5.50)$ & $0.26(1.73)$ & $0.19(7.12)$ \\
\hline Crude oil elasticity & $0.83(11.52)$ & $0.89(12.33)$ & $0.74(4.77)$ \\
\hline
\end{tabular}

$1 / t$-ratio in parenthesis. 
in many importing countries and prevent a trickling down of temporary declines in crude oil prices. Economic activity was a driving force as shown by the long-run income elasticities, which were significant and high: 1.53 in 1918-2004, 1.93 in 1918-73, and 0.80 in 1974-2004. Income elasticity underwent a structural change, falling to 0.80 in 1974-2004 from 1.93 in 1918-73. There was evidence, therefore, that the oil industry was largely competitive in 1918-73: the crude oil supply was growing at a faster rate than economic activity. The regrouping of producers and the big shocks in oil prices led to significant savings in the consumption of oil products, thus reducing the income elasticity. Nevertheless, the long-run income elasticity was still significantly high and close to unity, and changes in world economic activity could lead to significant changes in the demand for crude oil.

The existence of an integrating vector reflecting a long-run supply function for crude oil could not be rejected. The long-run supply price elasticity was significant and positive: 0.12 (1918-2004), 0.46 (1918-73), and 0.25 (1974-2004). Thus, unlike the short-term price elasticity, which was consistently low, the long-run price elasticity showed a positive response of output to prices. The huge drop in elasticity to 0.25 in 1973-2004 from 0.46 in 1918-73, however, shows a change from a competitive to a market-maker structure. Recognizing that demand had become extremely inelastic in 1973-2004, crude oil producers expanded supply only slightly to avoid a sharp drop in prices. The long-run natural gas output elasticity was significant: 0.78 in 1918-2004, 0.73 in 1918-73, and 0.45 in 1973-2004, showing a long-run interdependence of oil and natural gas output. The significant drop in this elasticity in 1973-2004 was indicative of a market structure with oil producers restraining supply to avoid a sharp drop in oil prices.

The long-run demand for natural gas underwent major structural changes. The price elasticity fell dramatically to -0.01 in 1974-2004 from -0.37 in 1918-73. The price shocks after 1973 might have compressed demand to minimum levels, which cannot be reduced further without impeding economic activity or consumers' welfare. The income elasticity was significant and high: 1.78 in 1918-2004, and 2.35 in 1918-73. It fell dramatically to 0.88 in 1974-2004. Thus, growth in economic activity is a key determinant in demand for natural gas. Similar to the crude oil demand function, the significant decline in the long-run income elasticity in 1973-2004 unravels an energy-saving bias and a less elastic consumption structure for natural gas. A cointegrating vector for a long-run supply function could not be rejected. The long-run supply of natural gas had significant price elasticities: 0.34 in 1918-2004, 0.26 in 1918-73, and 0.19 in 1974-2004. The long-run supply of natural gas is therefore responsive to price signals. Facing a long-run demand schedule that was elastic to both price and real GDP, natural gas producers did not anticipate that expanding supply would have a depressing effect on prices. The elasticity of crude oil output was high and significant: 0.83 in 1918-2004, 0.89 in 1918-73, and 0.74 in 1974-2004. Thus, natural gas output is closely correlated with crude oil output. The stability of the crude oil elasticity over the entire period 1918-2004 shows that natural gas and crude oil supply are technically interdependent and that discoveries and development of natural gas are closely related to discoveries and development in crude oil production. 


\section{Comparison with Findings in Other Studies and Implications for Market Equilibrium}

The findings of this paper agree more with the empirical research that tends to yield low values for demand price elasticities both in the short and long run. The paper's findings are quite similar to those of the empirical research with respect to income elasticity, which is generally close to or higher than unity in both the short and long run. Differences between this paper's results and those of other studies could arise from various sources, including the specification of the model, the use of time series or cross-sectional data, properties of the error terms, and the estimation methodology. Most studies on energy markets have dealt with energy demand and relied mainly on cross-sectional data, which are thought to be able to overcome identification problems and to adequately determine long-run equilibrium (Table 3). Despite these differences, there is a consensus on a highly price-inelastic demand schedule in the short run and a more elastic, although still lower-than-unity, demand price elasticity in the long run. Results for energy supply elasticities are scarce. Supply behavior in the energy sector, unlike that in the agricultural sector, has not received much attention: the priority in analyzing the impact of oil shocks has been on the demand side in order to study energy-saving, substitution behavior, and its implications for inflation, employment, and growth.

The price inelasticity of both demand and supply has implications for equilibrium prices and explains the volatility of these prices. Focusing on the implications of the short-run price inelasticity of the demand for crude oil, a reduction in crude oil supply, ${ }^{11}$ described by a leftward shift in the supply schedule, is likely to entail a large short-run increase in crude oil prices. ${ }^{12}$ Similarly, an increase in crude oil supply, described by a rightward shift in the supply schedule, is likely to entail a large short-run drop in crude oil prices. With respect to the price inelasticity of the supply of crude oil, a drop in demand for crude oil (a leftward shift of the demand schedule) — for instance, caused by a slowdown in world economic activity or a warmer winter in the Western countries - would cause crude oil prices to fall sharply. Similarly, a rise in demand (a rightward shift of the demand schedule), stemming for instance from a faster-growing world economy or a severe winter in the Western countries, would entail a large increase in crude oil prices.

${ }^{11}$ A shock to supply could be a strike by oil workers or regional events.

12 Similar comparative statics apply for natural gas. 
Table 3. Estimates of Demand Elasticities from Other Energy Studies 1/

\begin{tabular}{|c|c|c|c|c|c|c|}
\hline Author(s) & $\begin{array}{l}\text { Type of } \\
\text { demand }\end{array}$ & Elasticity & $\begin{array}{l}\text { Liquid } \\
\text { Fuels }\end{array}$ & $\begin{array}{l}\text { Natural } \\
\text { Gas }\end{array}$ & Gasoline & Energy \\
\hline \multirow[t]{3}{*}{ Pyndick (1979) } & Residential & LR price & {$[-1.0,-1.25]$} & -1.7 & & \\
\hline & Industrial & LR price & {$[-0.22,-1.17]$} & {$[-0.41,-2.34]$} & & \\
\hline & Transport & LR price & & & -1.31 & \\
\hline Houthakker, Verleger, and & & SR price & & & -0.075 & \\
\hline Sheehan (1974) & & LR price & & & -0.24 & \\
\hline $\begin{array}{l}\text { Ramsey, Rasche, and Allen } \\
\text { (1975) }\end{array}$ & & LR price & & & -0.7 & \\
\hline $\begin{array}{l}\text { Adams, Graham, and Griffin } \\
\text { (1974) }\end{array}$ & & LR price & & & -0.9 & \\
\hline \multirow[t]{4}{*}{ Dhal and Sterner (1991) } & & SR price & & & {$[-0.22,-0.31]$} & \\
\hline & & LR price & & & {$[-0.8,-1.01]$} & \\
\hline & & SR income & & & {$[0.44,0.52]$} & \\
\hline & & LR income & & & {$[1.1,1.38]$} & \\
\hline \multirow[t]{4}{*}{ Bentzen and Engsted (1993) } & & SR price & & & & -0.13 \\
\hline & & LR price & & & & -0.46 \\
\hline & & SR income & & & & 0.41 \\
\hline & & LR income & & & & 1.21 \\
\hline \multirow{10}{*}{$\begin{array}{l}\text { Pesaran, Smith, and } \\
\text { Akiyama (1998) }\end{array}$} & Aggregate & LR price & & & & -0.33 \\
\hline & & LR income & & & & 1.18 \\
\hline & Industry & LR price & & & & -0.52 \\
\hline & & LR income & & & & 1.24 \\
\hline & Transport & LR price & & & & -0.36 \\
\hline & & LR income & & & & 1.41 \\
\hline & Residential & LR price & & & & -0.47 \\
\hline & & LR income & & & & 0.95 \\
\hline & Commercial & LR price & & & & -0.08 \\
\hline & & LR income & & & & 0.62 \\
\hline \multirow[t]{2}{*}{ Balestra and Nerlove (1966) } & & LR price & & -0.63 & & \\
\hline & & LR income & & 0.62 & & \\
\hline \multirow[t]{4}{*}{ Rice \& Smith (1977) } & & SR price & & & -0.35 & \\
\hline & & LR price & & & -0.45 & \\
\hline & & SR income & & & 0.56 & \\
\hline & & LR income & & & 0.71 & \\
\hline \multirow[t]{4}{*}{ Data Resources (1973) } & & SR price & & & -0.07 & \\
\hline & & LR price & & & -0.28 & \\
\hline & & SR income & & & 0.35 & \\
\hline & & LR income & & & 1.0 & \\
\hline \multirow[t]{4}{*}{ Philips (1972) } & & SR price & & & -0.11 & \\
\hline & & LR price & & & -0.68 & \\
\hline & & SR income & & & 0.58 & \\
\hline & & LR income & & & 1.54 & \\
\hline
\end{tabular}


The interaction between crude oil and natural gas supplies has a bearing on crude oil prices. An increase in the natural gas supply would be accompanied by an increased supply of crude oil (a rightward shift of the crude oil supply schedule) and would cause a significant fall in crude oil prices. A reduced supply of natural gas would be accompanied by a reduction in the crude oil supply (a rightward shift of the crude oil supply schedule) and would cause a significant increase in crude oil prices.

\section{Relation Between Oil Prices, Interest Rates, and THE U.S. DOLLAR NEER}

Having estimated a structural model for oil markets, it is important to identify shocks that may affect oil prices. In this section, attention is given to shocks arising from monetary policy — namely, shocks to interest and exchange rates. The period 2000-04 witnessed low interest rates and a depreciating U.S. dollar (Figure 2). Worldwide low interest rates stimulate aggregate demand, and therefore, energy demand. Over the period 2000-04, the NEER of the dollar has depreciated by 13 percent. ${ }^{13}$ Because oil prices are denominated in dollars, this depreciation makes oil imports cheaper in local currencies. Moreover, oil exporters would like to seek higher prices to make up for the dollar's depreciation by tightening supply. ${ }^{14}$ A similar episode occurred during the 1970s when the dollar was depreciating and oil prices were moving upward rapidly. However, during 1980-85, interest rates were high, leading to an appreciation of the dollar's NEER by 39 percent, making oil imports more expensive in local currencies and at the same time depressing oil prices.

A vector autoregressive model (VAR) is used to analyze cointegration between crude oil prices, the dollar's NEER, and U.S. interest rates based on monthly, quarterly, and annual data (Table 4). ${ }^{15}$ VAR analyses do not reject the existence of at least one cointegration relation. Although the cointegrating coefficients change both in sign and statistical significance according to frequency, sample period, and the number of lags, ${ }^{16}$ there is

\footnotetext{
${ }^{13}$ In part under the effect of the uncovered interest parity. The dollar has also depreciated by 48 percent against the euro from October 2000 through November 2004.

${ }^{14}$ Oil exporters whose local currencies appreciate may see their profit margins fall. Higher crude prices in dollar terms will help to recuperate losses from currency appreciation.

${ }^{15}$ The interest rates used are the federal funds rate, the three-month Treasury bill, and the ten-year government bond yield. Because of capital mobility across many countries, U.S. interest rates tend to influence interest rates in the rest of the world.

${ }^{16}$ This is evident since oil prices are also determined by other key variables as explained in the structural model.
} 


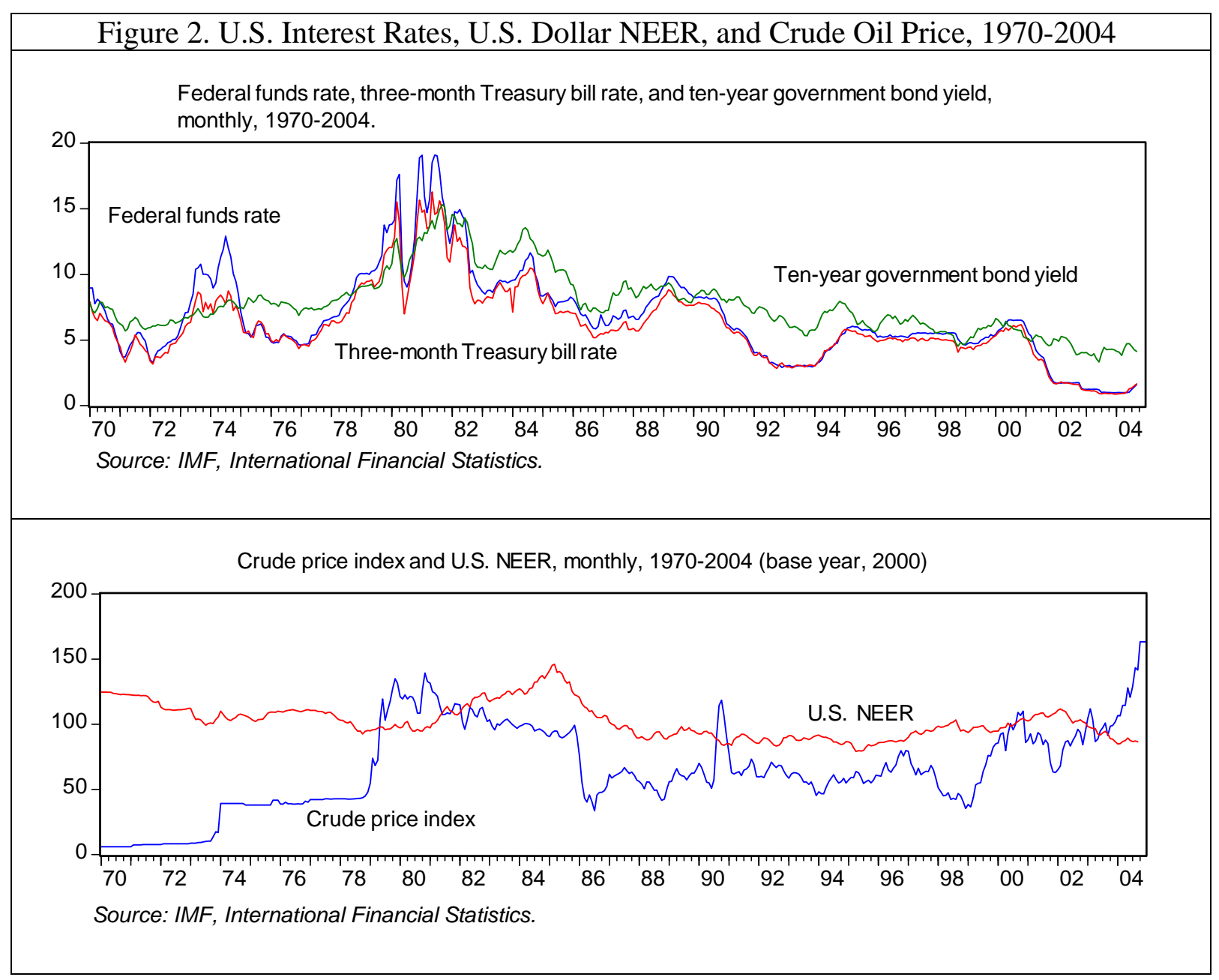

nevertheless a stylized relation during periods of large movements in interest and exchange rates. While an interest rate shock generally affects negatively and significantly oil prices for most of the sample periods, the effect of a NEER shock is significantly negative essentially during periods of large movements in interest and exchange rates. Impulse responses of the crude price to shocks are shown for periods of strong monetary impetus (Figure 3). A pattern of response describes a negative effect of positive shocks to the NEER and interest rates. Noticeably, crude prices tend to fall in response to rising interest rates and an appreciation of the NEER, and to firm up in response to falling interest rates and a depreciation of the NEER. A positive random shock to crude price causes, on impact, crude price to increase. However, this effect is quickly dampened under the negative effect of shocks from interest rates and the NEER. As an implication of vulnerability to monetary shocks, coordination of monetary policy among industrial countries should pay due regard to oil markets' volatility, and a Taylor-like rule should explicitly include crude price volatility in the inflation target. 
Table 4. Cointegrating Relations Between Crude Price, the NEER, and Interest Rates 1/

\begin{tabular}{|c|c|c|c|c|}
\hline $\begin{array}{l}\text { Crude } \\
\text { Oil Price }\end{array}$ & NEER & $\begin{array}{c}\text { Treasury Bill } \\
\text { Rate }\end{array}$ & Constant & Frequency and Sample \\
\hline 1 & $-7.76(-3.06)$ & $0.28(2.54)$ & 31.02 & Sample: 1974M01 2004M09 \\
\hline 1 & $-12.30(-3.14)$ & $0.47(2.75)$ & 50.70 & Sample: 1974Q1 2004Q3 \\
\hline 1 & $-8.79(-0.38)$ & $0.16(3.15)$ & 15.28 & Sample: annual 19742004 \\
\hline 1 & $1.46(3.04)$ & $0.09(3.86)$ & -10.26 & Sample: 2000M01 2004M09 \\
\hline 1 & $2.86(3.29)$ & $0.09(1.87)$ & -17.78 & Sample: 1979M01 1986M12 \\
\hline 1 & $1.12(1.58)$ & $0.09(2.16)$ & -8.38 & Sample: 1984Q4 2004Q3 \\
\hline 1 & $1.24(2.73)$ & $0.08(3.6)$ & -9.27 & Sample: 2000Q1 2004Q3 \\
\hline 1 & $5.49(3.03)$ & $0.23(2.14)$ & -31.37 & Sample: 1978Q1 1986Q4 \\
\hline 1 & $2.46(8.29)$ & $0.04(6.74)$ & -6.40 & Sample: annual 19902004 \\
\hline
\end{tabular}

1/ The crude price and the NEER are in logarithms; $t$-ratios in parenthesis.

Figure 3: Impulse Responses from a VAR for Crude Price, NEER, and Interest Rates

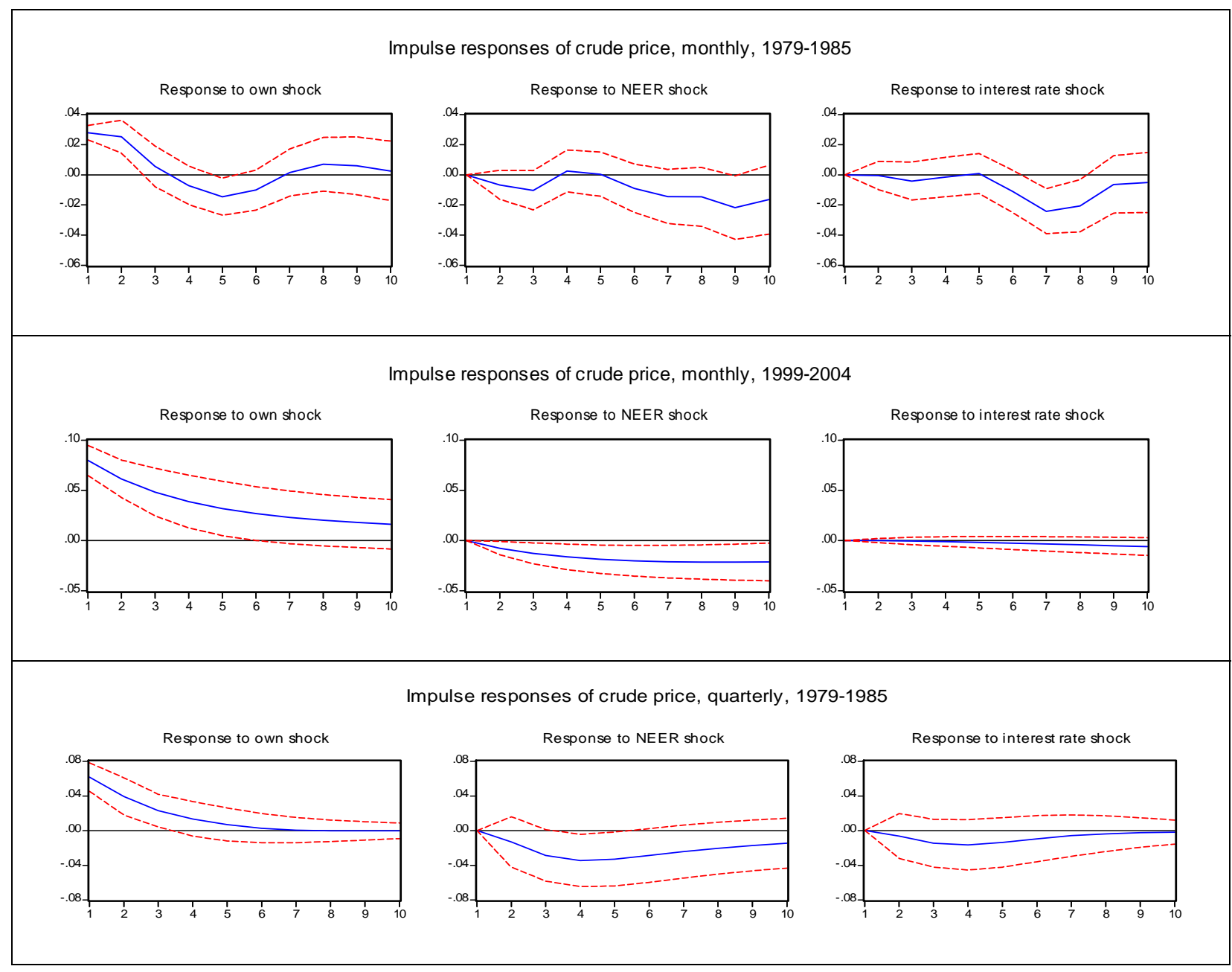




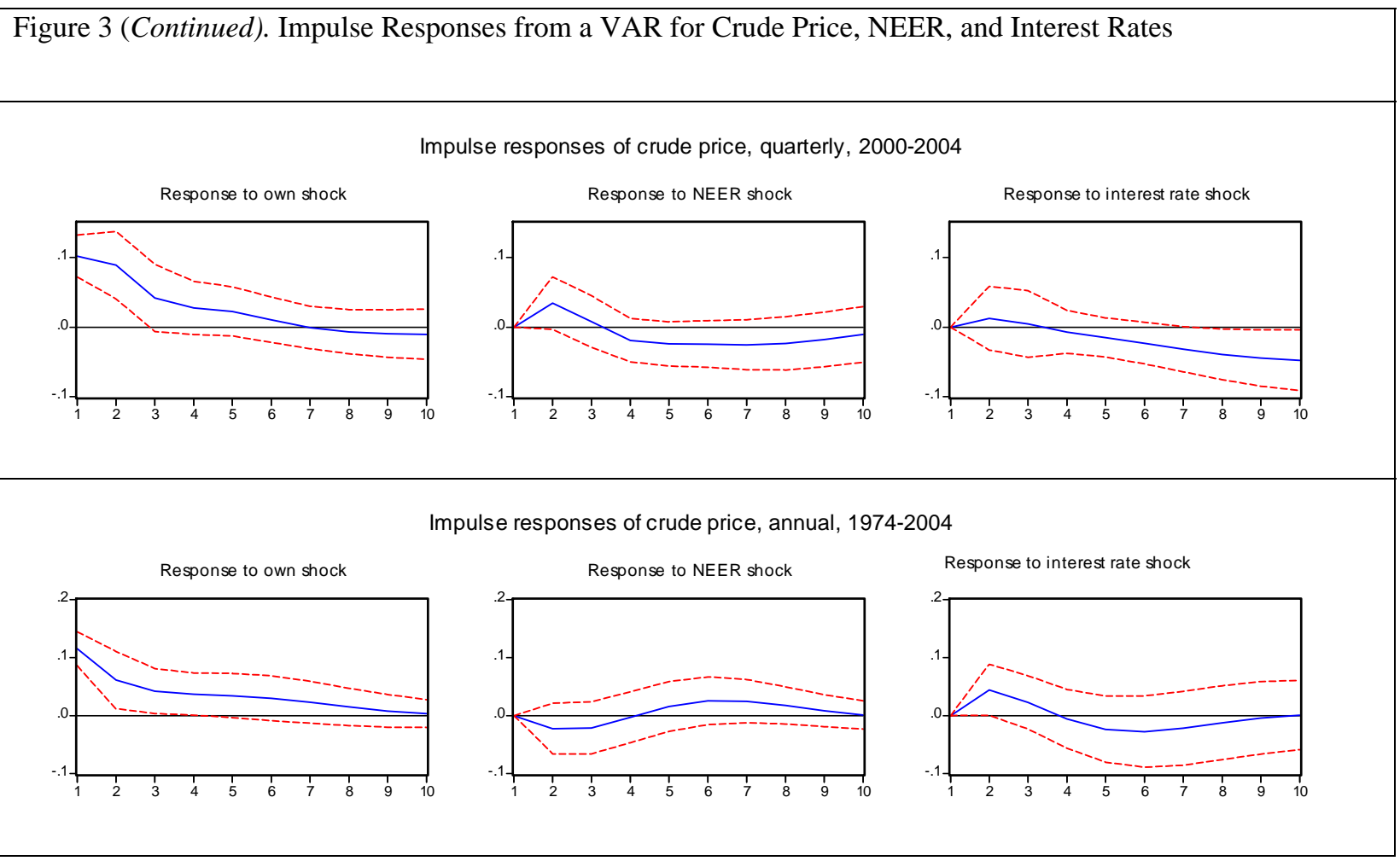

\section{EXTENSION AND SOLUTION OF THE SEM}

\section{A. Role of the NEER in the Crude Oil and Natural Gas Markets}

Monetary policy affects aggregate demand and subsequently demand for energy. Moreover, changes in the dollar's NEER affect import prices of energy in local currencies and therefore world demand for crude oil and natural gas to the extent that these two products are priced in dollars. For this reason, the SEM is extended to incorporate the NEER as an exogenous variable and reestimated for 1974-2004 (Table 5). ${ }^{17}$ Reestimation for 1918-73 was not done because data on NEER were not available for most of this period. An appreciation of the NEER, stemming from high interest rates and a contracting aggregate demand, has a significant negative short-term impact on the crude oil price as well as on the demand and supply for crude oil. It has also a negative short-term effect on the demand for natural gas. The long-run effect of the NEER is generally negative on both demand and supply of crude oil and on the demand for natural gas. An appreciation of the NEER would most likely depress oil and natural gas markets, whereas a depreciation would have an opposite effect.

\footnotetext{
${ }^{17}$ The interest rates have significant coefficients with expected signs in the SEM. However, for parsimony, they are not explicitly shown in the SEM because their effect is transmitted through real GDP and the NEER.
} 


\section{B. Solution of the SEM}

The SEM can be written as $B y_{t}+C z_{t}=u_{t}$, where $y_{t}$ is the vector of endogenous variables, $z_{t}$ is the vector of exogenous and predetermined variables, and $u_{t}$ is the vector of error terms satisfying $E\left(u_{t}\right)=0$ and $E\left(z_{j t} u_{i t}\right)=0$. The solution of the model can be written in reduced form as: $\hat{y}_{t}=-\hat{B}^{-1} \hat{C} z_{t}$. Knowledge of the exogenous variables will enable one to forecast the endogenous variables. The actual and fitted values for the endogenous variables are shown in Figure 4. The SEM closely fits the data. The residuals are serially uncorrelated; their standard errors are small and estimated at 0.009 for crude oil output, 0.03 for crude oil price, 0.006 for natural gas output, and 0.02 for the natural gas price. The model predicts closely the quantities for crude oil and natural gas; however, price prediction is less precise, particularly for the crude oil price, since the latter has shown large fluctuations in the period 1974-2004. The multipliers of the SEM give the long-run effect of a unit change in an exogenous variable on the endogenous variables. In this respect, a 1 percent increase in income leads to an increase in crude oil output by 0.49 percent, crude oil price by 1.25 percent, natural gas output by 1.0 percent, and natural gas price by 2.53 percent. Thus, an expansion of world economic growth could exert a strong upward pressure on oil and natural gas prices. For the NEER, a 1 percent depreciation leads to an increase by 0.62 percent in the crude oil price and 0.83 percent in the natural gas price.

Table 5: World Crude Oil and Natural Gas: The SEM Extended to Include the NEER

\begin{tabular}{lrr}
\hline & Short-Run Elasticities & Long-Run Elasticities \\
\hline Crude oil demand & & \\
Price elasticity & $-0.004(-0.20)$ & $-0.17(-1.56)$ \\
Income elasticity & $1.43(4.07)$ & $0.63(4.90)$ \\
NEER elasticity & $-0.08(-2.21)$ & $-0.26(-1.34)$ \\
Crude oil supply & & \\
Price elasticity & $-0.03(-1.13)$ & $-0.08(-0.88)$ \\
Natural gas elasticity & $1.60(4.72)$ & $1.09(12.46)$ \\
NEER elasticity & $-0.12(-2.28)$ & $-0.90(-3.91)$ \\
Natural gas demand & & $-0.01(-2.08)$ \\
Price elasticity & $0.10(3.58)$ & $0.85(43.55)$ \\
Income elasticity & $0.61(3.29)$ & $-0.14(-4.36)$ \\
NEER elasticity & $-0.12(-4.02)$ & \\
Natural gas Supply & & $0.10(4.16)$ \\
Price elasticity & $0.06(1.85)$ & $1.29(9.37)$ \\
Crude oil elasticity & $0.41(5.33)$ & $0.21(1.61)$ \\
NEER elasticity & $0.05(2.34)$ & \\
\hline
\end{tabular}

1/ t-ratio in parenthesis. 
Figure 4: Actual and Fitted Values and Residuals of the SEM

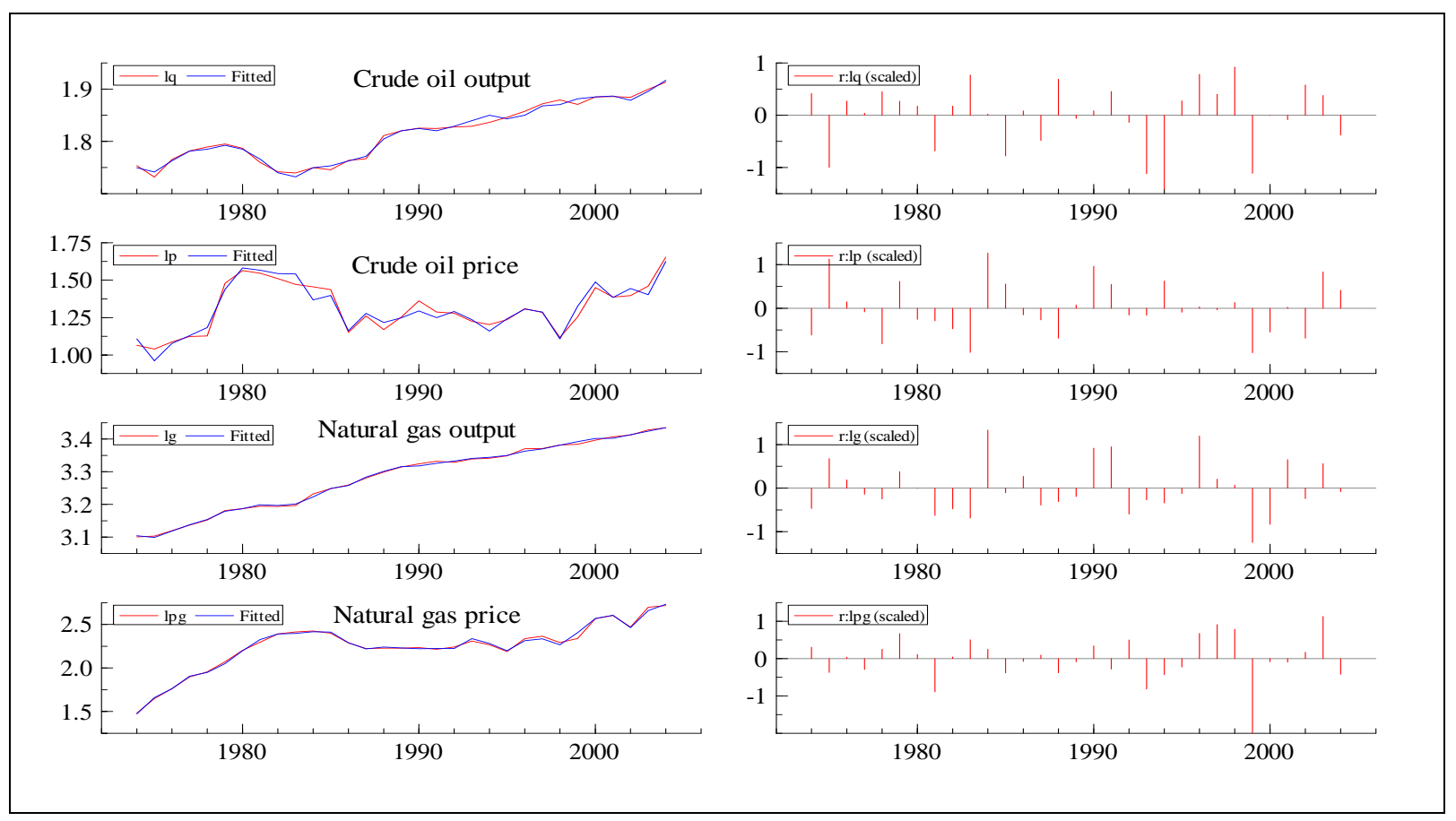

\section{Conclusions}

This paper has studied the oil and natural gas markets over the period 1918-2004, juxtaposing the market equilibrium that existed before and after the 1973 oil shock. Oil shocks caused the demand for crude oil and natural gas to decelerate sharply in 1973-2004, yet without constraining long-term world economic growth. This observation is important and shows that the world economy has a significant potential for adjusting to oil shocks through substitution and efficiency, alleviating thus elasticity pessimism. A SEM embedding demand and supply functions was estimated for both the short and long run. This distinction is essential because short- and long-run equilibrium may differ; it enables one also to comprehend fully the dynamics of the crude oil and natural gas markets. Demand and supply for both crude oil and natural gas were highly price inelastic in the short run, leading to excessive volatility in oil and natural gas markets. Demand for crude oil underwent a deep structural change in 1973-2004. Notably, upward jumps in oil prices, along with high energy taxation in oil-importing countries, contributed to a significant reduction of the demand elasticities by compressing, through energy saving and substitution, long-run demand for oil to a nonelastic region, with demand for liquid fuels increasingly limited to transportation. Income elasticities were high for both crude oil and natural gas demand. Long-run supply price elasticity for crude oil fell sharply after the oil shock, reflecting a change from a competitive to a market-maker structure. The same elasticity for natural gas in the vector error correction model rose, however, reflecting a flexible supply response to a switch in demand toward natural gas. 
The paper attempted to analyze the effect of monetary policy on oil prices; it showed that changes in interest rates and in the dollar's NEER could have a significant impact on oil prices: namely, falling interest rates and a depreciating NEER could lead to a surge in oil prices, and inversely. This finding establishes that oil and natural gas prices would continue to be under upward pressure so long interest rates keep falling and the dollar's NEER keeps depreciating. As an implication, coordination of monetary policy among industrial countries should include volatility of oil markets separately in the inflation target.

The SEM, being a structural model, has many potential applications for industry analysts and policymakers. It could simulate over time the impact of a change in an exogenous variable via dynamic multipliers. It can also simulate the impact of random shocks to demand and supply of crude oil and natural gas via the impulse response functions. This, however, would require an identification scheme to define shocks. Demand shocks operate in the demand function and may arise from shocks to real GDP, and interest and exchange rates. Supply shocks operate in the supply function and may arise from shocks to actual or capacity output. Given the stability and reliability of the elasticity estimates, a forecast of prices using SEM could provide realistic and relevant information for market traders. Because the model is estimated in structural form, sensitivity analysis can be performed on one or more structural parameters. 


\section{Appendix. Data sources}

Arthur Andersen/Cambridge Energy Research Associates, Natural Gas Trends, 1985-2003.

Arthur Andersen/Cambridge Energy Research Associates, World Oil Trends, 1985-2003.

Cambridge Energy Research Associates: World Oil Watch, various reports, 1995-2003.

Commodity Research Bureau, Commodity Yearbook, John Wiley \& Sons, Inc. 1955, 1965, 1975, 1985, and 1996.

International Energy Agency: Oil Market Report, various reports, 1995-2004.

International Energy Agency, Energy Statistics and Balances of Non-OECD Countries, various publications, 1985-2004.

International Monetary Fund, International Financial Statistics, 1950-2004.

Mitchell, B. R., International Historical Statistics, the Americas and Europe, 1750-1993, Fourth Edition, Macmillan, 1998.

Oil and Gas Journal, Worldwide Crude Oil and Gas Production, 2003.

Oil and Gas Journal, Database, 2003.

OPEC, Annual Statistical Bulletin, various publications, 1980-2003.

Petroleum Economist, various publications, 1985-2004.

United Nations, World Energy Supplies, 1950-1974, New York, 1976.

U.S. Bureau of Mines, The Petroleum Data Book, 1950.

U.S. Department of Commerce, Bureau of the Census, Historical Statistics of the United States, 1975.

U.S. Department of Energy, Twentieth Century Petroleum Statistics, 1990. 


\section{REFERENCES}

Adams, F. G., H. Graham, and J. M. Griffin, 1974, “Demand Elasticities for Gasoline, Another View,” Department of Economics, Discussion Paper No. 279, University of Pennsylvania.

Balestra, P., and M. Nerlove, 1966, "Pooling Cross Section and Time Series Data in the Estimation of a Dynamic Model: The Demand for Natural Gas,” Econometrica, Vol. 34, pp. 585-612.

Bentzen, Jan, and Tom Engsted,1993, “A Short- and Long-Run Elasticities in Energy Demand: A Cointegration Approach,” Energy Economics, Vol. 15, pp. 9-16.

Dahl, Carol, and Thomas Sterner, 1991, “Analyzing Gasoline Demand Elasticities: A Survey,” Energy Economics, Vol. 13, pp. 203-10.

Data Resources, 1973, “A Study of the Quarterly Demand for Gasoline and Impacts of Alternative Gasoline Taxes, Prepared for Council on Environmental Quality.”

Hausman, Jerry A., Whitney K. Newey, and William E. Taylor, 1987, "Efficient Estimation and Identification of Simultaneous Equations Models with Covariance Restrictions,” Econometrica, Vol. 55, pp. 849-74.

Houthakker, H. S., and L. D. Taylor, 1970, Consumer Demand in the United States: 19291970 (Cambridge, Mass., Harvard University Press, Second Edition).

Houthakker, H. S., P. K. Verleger, and D. P. Sheehan, 1974, "Dynamic Demand Analyses for Gasoline and Residential Electricity,” American Journal of Agricultural Economics, Vol. 56, 412-18.

McCallum, B. T., 1976, "Rational Expectations and the Natural Rate Hypothesis: Some Consistent Estimates,” Econometrica, Vol. 44, pp. 43-52.

Muth, John F., 1961, "Rational Expectations and the Theory of Price Movements," Econometrica, Vol. 29, pp. 315-35.

Pesaran, M. H., R. P. Smith, and T. Akiyama, 1998, "Energy Demand in Asian Developing Economies,” A World Bank Study (Oxford University Press).

Philips, Louis, 1972, "Dynamic Version of the Linear Expenditures Model," Review of Economics and Statistics, Vol. 54, pp. 450-570.

Pindyck, Robert S., 1979, The structure of World Energy Demand (MIT Press, Cambridge, Massachusetts).

Ramsey, J., R. Rasche, and B. Allen, 1975, “An Analysis of the Private and Commercial Demand for Gasoline,” Review of Economics and Statistics, Vol. 57, pp. 502-07.

Rice, Patricia, and V. K. Smith, 1977, "An Econometric Model of the Petroleum Industry," Journal of Econometrics, Vol 6, pp. 263-87. 